\title{
Application of banana spathe extracts and compost for improving growth in rice plants
}

\author{
Suganthi Selvam, Kavitha Saravana Kumar* \\ Department of Plant Biology and Plant Biotechnology, Ethiraj College for Women affiliated to University of Madras, Chennai- 600 008, India.
}

\section{ARTICLE INFO \\ Article history: \\ Received on: October 30, 2021 \\ Accepted on: December 20, 2021 \\ Available online: January 07, 2022}

\section{Key words:}

Agrowaste, compost, banana

spathe, rice

\begin{abstract}
The application of agro-waste in the form of compost is an ecofriendly approach to minimize the use of chemicals for crop improvement. Hence, compost was prepared by the Indore method from banana spathe obtained from five popular varieties of banana cultivated in Tamil Nadu, India, and its growth promoting ability was tested on the rice cultivar CO-51. The banana spathe was applied as both an aqueous extract and compost to evaluate the growth parameters in bioassays and pot culture experiments. The compost improved the growth in terms of root length, shoot length, biomass, tillers, length, and width of flag leaf and yield in CO-51 rice cultivar significantly $(p<0.001 \%)$ when compared to the untreated control and fertilizer-treated plants. The maximum yield was observed in the treatment with Rasthali spathe. Biochemical analysis of the compost-treated rice plants showed an increase in chlorophyll, carotenoid, carbohydrate, protein, and amino acid content when compared to the untreated control plants. The results from the study suggest that the banana spathe compost could be used as an effective organic fertilizer for the growth of rice plants thus providing a strategy to reduce landfills, as well as the use of fertilizers, thereby further helping to protect the agroecosystem.
\end{abstract}

\section{INTRODUCTION}

Although agriculture is considered the backbone of India, it still faces environmental problems due to the application of an enormous amount of chemical fertilizers and pesticides to improve crop production. Continuous application of nitrogenous fertilizers deteriorates the soil fertility which in turn leads to the lower productivity of the crop and moreover it is costly when compared to organic fertilizers $[1,2]$. In this scenario, the production and application of organic fertilizers that do not harm the environment could prove to be an effective strategy to safeguard the environment. In fact, they are the most suitable source for enhancing soil fertility as well [3]. Organic compost promotes the soil with better water-holding capacity and drought resistance. It is also popularly known for its ecofriendly and economically attractive nature. More often, it also helps in sustainable management of agroresidues and enhancing the recycling capacity of substrates that are generated in agricultural industry $[4,5]$. When such organic composts are

*Corresponding Author

Kavitha Saravana Kumar, Department of Plant Biology and Plant Biotechnology, Ethiraj College for Women affiliated to University of Madras, Chennai, India.E-mail:drkavi76@gmail.com prepared from plant parts that possess phytoconstituents like phenols and alkaloids, they provide a better and safe environment for the crop plants to which they are applied as a fertilizer. The phytoconstituents present in the compost may help in combating harmful microbes that may cause damage to the crop [6-8].

Common among the agrowastes are postharvest wastes, cassava peels, peanut shells, vegetable and fruit peels, brewery wastes, cocoa husks, kola husks, corn, etc. $[4,9,10]$. These agrowastes can be composted and used as a value-added biofertilizer [11]. Composting of these agrowastes is considered to be more ecofriendly than municipal waste because of its less heavy metal content [12]. Although a number of raw materials from agrowaste are available, there is always a constant search for new sources to find a better substrate that has a higher nutrient value to replace the chemical fertilizers.

In India, particularly in the southern states, among the major fruit crops cultivated, Musa sp. (Banana), belonging to the family Musaceae, has a major role in the generation of postharvest residues. They are mainly grown in the tropical and sub-tropical countries and are widely used for their nutritional values all over the world. 
Various plant parts are obtained as agrowastes from banana cultivation. Studies have been carried out on compost production from banana waste like peels, pseudostems, and dry leaves obtained from different varieties [13]. However, a highly nutritious and lignin-rich spathe, a part of the banana spadix, is being discarded as waste in markets and cultivated areas. So far, it has not been exploited as a raw material for compost generation. It is highly nutritious and lignin-rich and hence can be used as a source of compost for plants as they are highly nutritious and rich in lignin content. Hence, in the present study, banana spathe is used as a raw material for the preparation of organic compost and rice cultivar CO-51 has been used as a model plant for evaluating the potential of the compost. Herein, we report that banana spathe, a neglected agrowaste from banana fields and markets, can be effectively utilized as a compost substrate and has a great potential to improve the growth in crop plants.

\section{METHODS AND MATERIALS}

\subsection{Sample Preparation and Extraction}

Banana flower spathe of five popular varieties, namely Karpuravalli (MV1), Poovan (MV2), Plantain (MV3), Elaki (MV4), and Rasthali (MV5), were collected from different banana-cultivated areas in Ranipet district of Tamil Nadu. They were shade-dried for about 40-50 days and powdered. These powdered samples were extracted using different solvents such as aqueous, ethanol, and methanol in the ratio of 1:10 (plant sample:solvent) by cold percolation method and were stored at $4^{\circ} \mathrm{C}$ [14].

\subsection{Preparation of Compost Using Heap Method}

The banana spathe compost (BSC) was prepared in earthen pot containers of size $15 \times 18$ inches (width $\times$ length). Banana spathe was collected from five different varieties, viz. Karpuravalli, Poovan, Plantain, Elaki, and Rasthali. The base of the heap was lined with neem twigs to avoid pests. The spathe portions were added in successive layers and piled up on top of the neem sticks [15]. The compost was collected after 90 days and stored in airtight packs after sieving.

\subsection{Nutrient Analysis of BSC}

Physiochemical factors such as $\mathrm{pH}$, electrical conductivity, organic carbon, $\mathrm{N}, \mathrm{P}, \mathrm{K}, \mathrm{Ca}, \mathrm{Mg}$, and $\mathrm{Na}$ were analyzed for soil and total nutrients were analyzed for BSC used for pot culture experiments.

\subsection{Phytochemical Analysis of Musa Extract and Compost}

The extracts of Musa spathe of the selected varieties and the BSC were analyzed for the presence of alkaloids, tannins, glycosides, carbohydrates, proteins, amino acids, flavonoids, and saponins using standard procedures [16].

\subsection{Detection of Indole Acetic Acid and Total Phenolic Content}

Indole Acetic Acid (IAA) was determined by using Salkowski's reagent [17] and total phenolic content was determined by FolinCiocalteu's reagent by using gallic acid as the standard [18] in banana spathe extract.

\subsection{Effect of Banana Spathe Extracts on Rice Plants - Seed Germination and in vitro Bioassay}

The seeds of the rice cultivar CO-51 obtained from AGM/ TANSEDA, Arakkonam, Tamil Nadu, were used for all plate assays and pot culture experiments. The seeds were spread uniformly in petri dishes lined with sterile filter papers and treated with aqueous extracts of five different varieties of banana spathe extracts. All the experiments were carried out in triplicates. Germination and growth parameters such as radicle length and plumule length were recorded on the 7 th and 14th days after sowing (DAS). The percentage of seed germination was calculated and recorded.

\subsection{Effect of BSC on the Biometrics of Rice Cultivar CO-51 - A Pot Culture Experiment}

Polypropylene bags filled with soil mixture (red soil, sand, and clay) and compost in the ratio of 1:1 was used for the pot culture experiment. The soil used in the experiment was analyzed for its physicochemical properties before using it in the experiment. The rice seeds were soaked in water overnight and sown in the prepared polypropylene bag and given eight different treatments including control. The treatments are as follows:

1. Control plants grown without compost and fertilizer.

2. NPK - Plants grown with Conventional Nitrogen Phosphorus Potassium fertilizer (NPK used as per the recommended dosage).

3. BSC - Plants grown with soil and compost mixture.

4. T1 - Plants grown with aqueous extracts of MV1 Karpuravalli spathe.

5. T2 - Plants grown with aqueous extracts of MV2 Poovan spathe.

6. T3 - Plants grown with aqueous extracts of MV3 Plantain spathe.

7. T4 - Plants grown with aqueous extracts of MV4 Elaki spathe.

8. T5 - Plants grown with aqueous extracts of MV5 Rasthali spathe.

The growth parameters such as root length, shoot length, fresh weight, and dry weight were measured up to 120 days with 30 days interval. The number of tillers, flag leaf length and width, length of the panicle (90 DAS), and the yield (120 DAS) were also recorded and statistically analyzed.

\subsection{Estimation of Chlorophyll and Carotenoid pigments in Rice Cultivar CO-51}

The amount of chlorophyll-a, chlorophyll-b, and total chlorophyll in the leaves of rice plant (10 DAS) grown with different varieties of banana spathe extracts were analyzed by Arnon's method [19] and the carotenoid content by Harborne [16]. The amount of chlorophyll and carotenoid was calculated using the following formulae:

$$
\begin{aligned}
\text { Chlorophyll-a }(\mathrm{mg} / \mathrm{g})= & (12.7 \times \text { OD663 })-(2.69 \times \text { OD645 }) \times \\
& V / 1,000 \times W
\end{aligned}
$$




$$
\begin{aligned}
& \text { Chlorophyll-b }(\mathrm{mg} / \mathrm{g})=(22.9 \times \text { OD645 })-(4.68 \times \text { OD663 }) \times \\
& V / 1,000 \times W \\
& \text { Total chlorophyll }(\mathrm{mg} / \mathrm{g})=(20.2 \times \text { OD } 645)+(8.02 \times \text { OD } 663) \times \\
& V / 1,000 \times W \text {. } \\
& \text { Carotenoid }(\mathrm{mg} / \mathrm{g})=\text { OD480 }-(0.114 .3 \times \text { OD663 })-(0.638 \times \\
& \text { OD645) } \times V / 1,000 \times W \text {. }
\end{aligned}
$$

Where $V=$ volume of the sample and $W=$ weight of the sample.

\subsection{Estimation of Biochemicals - Carbohydrates, Proteins, and Amino Acids in Treated Rice Cultivar CO-51}

The compost-treated and untreated rice plants (90 DAS) were analyzed for the presence of carbohydrates by Anthrone's method [20]. Similarly, the estimation of protein and amino acid was carried out by using Bradford's method [21] and Ninhydrin [22]. Glucose, bovine serum albumin, and glycine were used as standards for carbohydrates, proteins, and amino acids, respectively.

\subsection{Statistical Analysis}

All the results recorded from the experiments conducted were statistically analyzed using Analysis of variance (Microsoft Excel 2010) and the means were compared using Duncan's Multiple Range Test [UNISTAT \& XLSTAT (2018)].

\section{RESULTS AND DISCUSSION}

BSC obtained after 90 days of the composting process had a blackish brown color with soil-like texture and without any odor. The yield of the compost was found to be half of the original raw material. In a similar study conducted by Kaur et al. [11], there was a change in the final texture and color (yellow to dark brown) in the compost prepared by using rice straw. The density of the rice straw was also found to be reduced at the end of the composting process [11]. The nutrient analysis revealed the presence of $0.77 \%$ nitrogen, $0.52 \%$ phosphate, and $0.98 \%$ potassium along with other essential minerals. The results were similar to a study conducted by Haposh et al. [23] in organic composts made from rice straw, cassava peel, and banana skin. The carbon-nitrogen ratio in the compost was found as 46:1 and the $\mathrm{pH}$ was recorded as 9.23 at the end of 90 days. The stability and maturity of the compost were determined based on these physicochemical parameters and nutrient content [24]. Since the C:N ratio was too high, the process of decomposition was running slow and hence the nitrogen content was completely utilized and was not lost in the form of ammonia. The process of decomposition was low as the banana spathe had higher lignin and cellulose content. $\mathrm{pH}$ was reduced to 8.1 once the rice cultivar $\mathrm{CO}-51$ was grown on the compost.

The phytochemical analysis of the aqueous, ethanolic, and methanolic extracts of Musa spathe of all the five different varieties and BSC showed the presence of carbohydrates, proteins, amino acids, phenolic compounds, tannins, phytosterols, saponins, terpenoids, fixed oils, and betacyanin, whereas the glycosides and alkaloids were absent as revealed by standard tests (Table 1). The phytochemicals act as a natural defense system for the host plants and they are responsible for the protection of such plants from environmental stress, microbial attack, insects, and other external aggression [25]. In the present study, the identification of phytochemicals like phenols, tannins, and terpenoids reveals the probable potentiality of spathe extracts and compost in combating naturally occurring harmful microorganisms in the soil, thereby promoting the growth of the plants [26]. The presence of phenol was found in all the five varieties of banana spathe and it was found to be maximum in the Poovan spathe extract (Fig. 1). Such a presence of phytochemical was observed in a study with banana flower extracts of Musa paradisiaca AAB Nendran variety [27]. In a study by Ogbonna et al. (2016), the presence of alkaloids, saponins, glycosides, and flavonoids were demonstrated in Musa species at three stages of development in fruits [25]. Thus, our study reports the presence of phytochemicals in banana spathe extracts that could probably account for the prolonged shelf life of the compost.

The presence of IAA was detected in all the five varieties of banana spathe extracts (Fig. 2) and the concentration of IAA was found to be maximum in the Poovan spathe extract compared to

Table 1: Phytochemical analysis of aqueous, ethanol, methanolic extracts of Musa spathe and BSC.

\begin{tabular}{clcccccc} 
S. No. & Name of the test & MV 1 & MV 2 & MV 3 & MV 4 & MV 5 & BSC \\
1. & Carbohydrate- Molisch's test & + & + & + & + & + & + \\
2. & Benedict's test & + & + & + & + & + & + \\
3. & Protein test- Millon's test & + & + & + & + & + & + \\
4. & Ninhydrin test & - & - & - & - & - & - \\
5. & Glycosides test- Borntrager's test & - & - & - & - & - & - \\
6. & Alkaloid test- Mayer's test & - & - & - & - & - & - \\
7. & Phenol test- Ferric chloride test. & + & + & + & + & + & + \\
8. & Flavanoids- Lead acetate & + & + & + & + & + & + \\
9. & Detection of Tannin & + & + & + & + & + & + \\
10. & Detection of phytosterol & + & + & + & + & + & + \\
11. & Saponin & + & + & + & + & + & + \\
12. & Terpenoids & + & + & + & + & + & + \\
13. & Fixed oil \& fats & + & + & + & + & + & + \\
14. & Test for Betacyanin & + & + & + & + & + & + \\
\hline
\end{tabular}

$(+)$ indicates presence; $(-)$ indicates absence. 


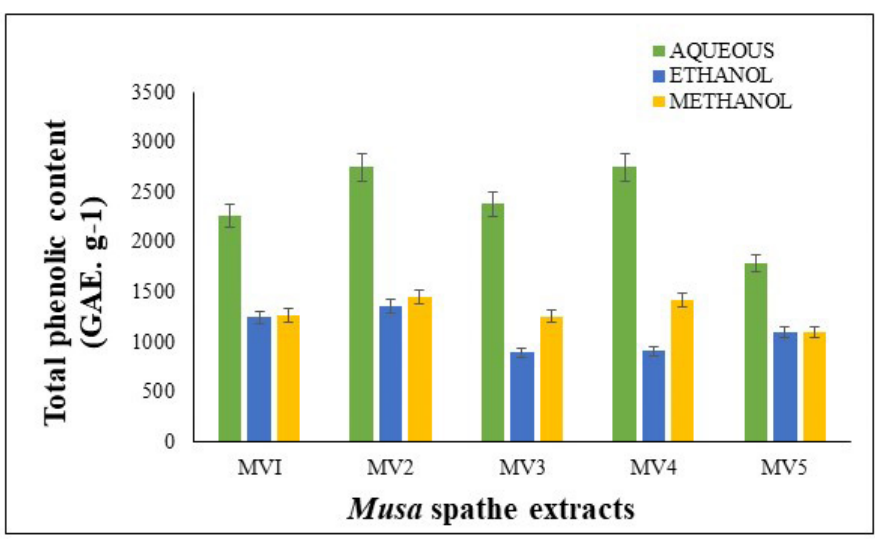

Figure 1: Concentration of total phenol in Musa spatte extracts.

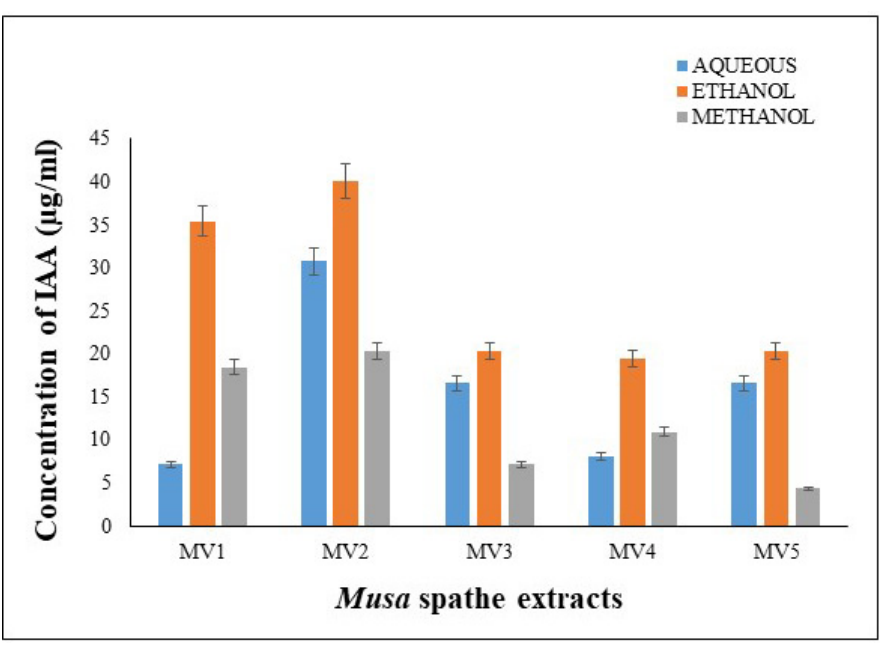

Figure 2: Concentration of IAA in Musa spathe extracts.

other varieties of Musa spathe extracts. This could have led to the promotion of the root and shoot lengths of the rice cultivar CO-51 in pot culture experiment. The role of L-tryptophan in plant growth promotion is not uncommon as revealed by a study conducted in maize plants [28]. Herein, the fruit and vegetable waste compost enriched with nitrogen and L-tryptophan led to the maximum growth and yield in them.

In vitro bioassays revealed that the germination of rice seeds of cultivar CO-51 was found to be high $(100 \%)$ in all the aqueous extracts of Musa varieties. The radicle and plumule length of the rice seedlings was found to be significantly $(p<0.001)$ increased in the presence of Musa spathe extracts of all the five varieties when compared to untreated control plants (Fig. 3).

In pot culture experiment biometric analysis revealed that the root length (Fig. 4) and shoot length (Fig. 5) of treated rice plants showed a significant increase $(p<0.001)$ in all the five treatments (T1, T2, T3, T4, and T5) when compared to BSC, NPK, and control (Fig. 14a). Such an increase in root and shoot lengths was observed in studies recorded in green gram and black gram plants treated with wheat bran and rice husk compost, respectively, for growth promotion $[29,30]$. Similarly, different organomineral fertilizers and compost of neem and cassava peel enhanced the

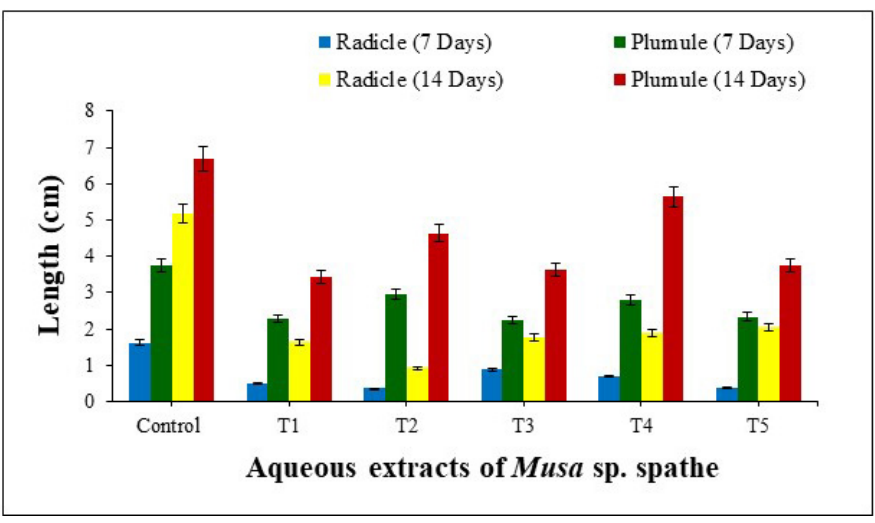

Figure 3: Growth of rice seedlings CO-51 in aqueous extract of Musa spathe.

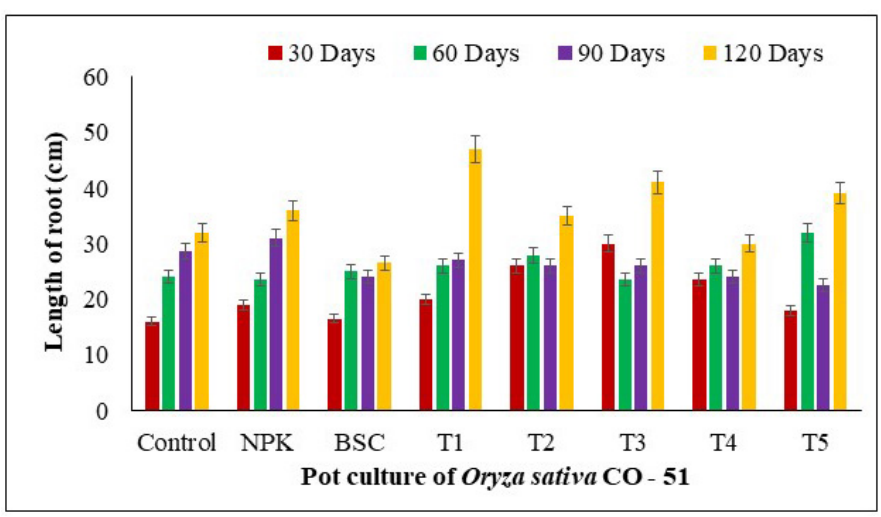

Figure 4: Root length of rice cultivar CO-51 treated with BSC and Musa spathe extracts-pot culture eaperiment.

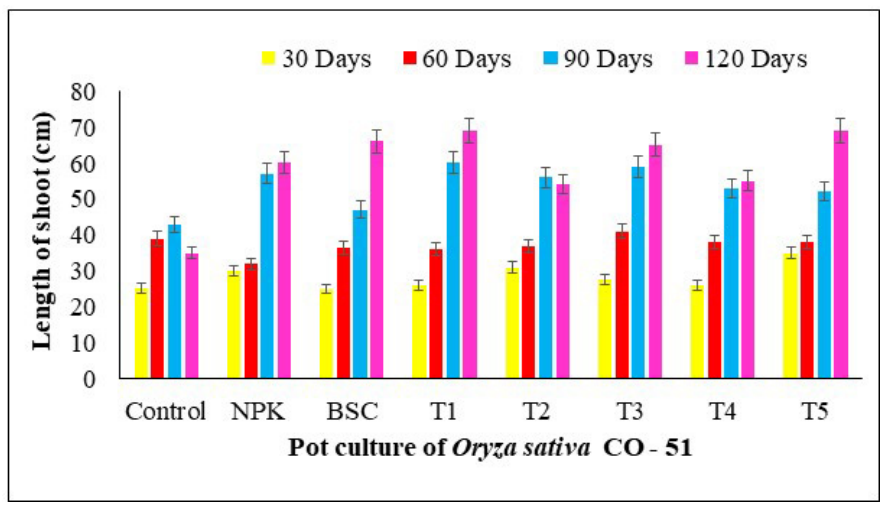

Figure 5: Shoot length of rice cultivar CO-51 treated with BSC and Musa spathe extracts - pot culture experiment.

growth and yield of two varieties of cabbage (Brassica oleracea L.), namely Copenhagen market and F1 milor [31].

The fresh weight and dry weight (Figs. 6-9) of the treated rice plants showed a significant increase $(p<0.001)$ when compared to BSC, NPK, and control plants. The results obtained were similar to a study made by Ipinmoroti and Akanbi in compost-treated cashew seedlings (organic nutrient sources) [32]. Lee et al. [33] also reported that there was a significant increase in fresh weight of cabbage on application of farmyard manure (FYM). 


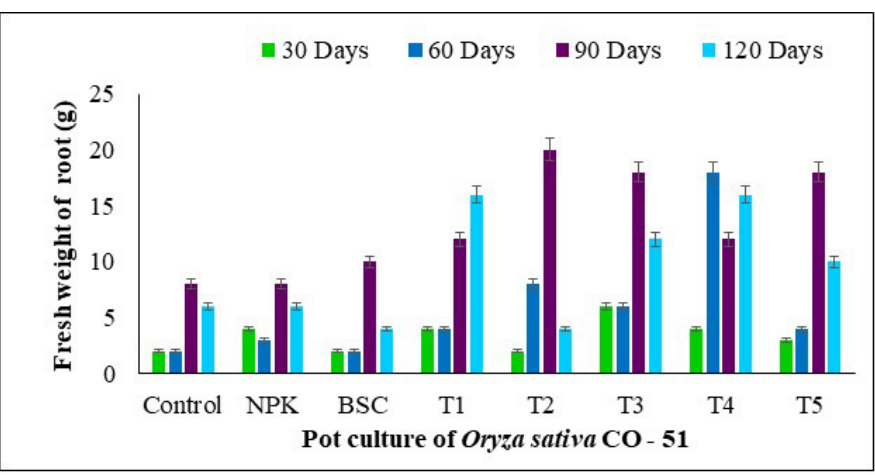

Figure 6: Fresh weight of root in rice cultivar CO-51 treated with BSC and Musa spathe extracts-pot culture experiment.

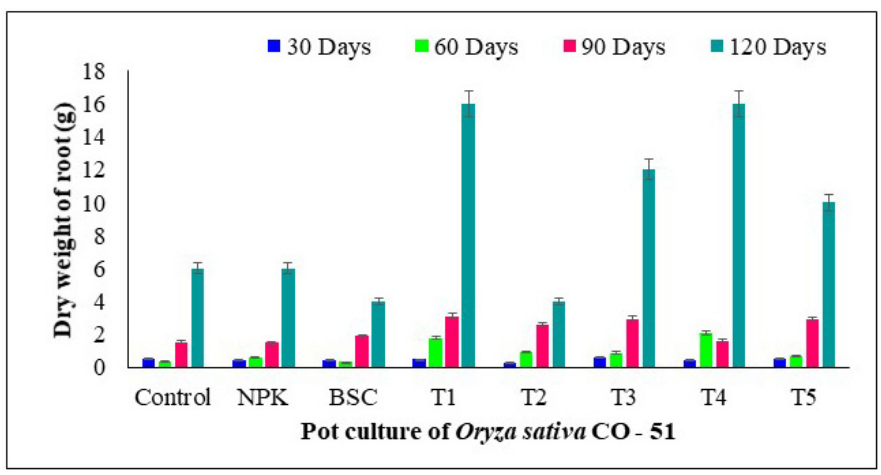

Figure 7: Dry weight of root in rice cultivar CO-51 treated with BSC and Musa spathe extracts-pot culture experiment.

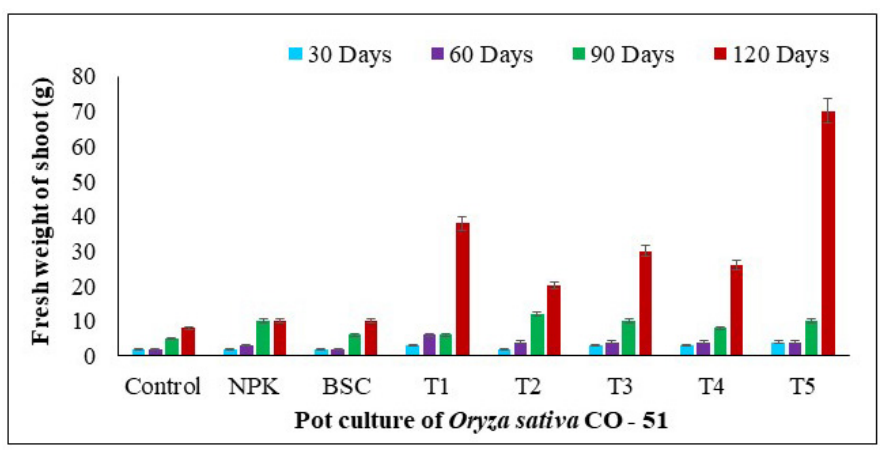

Figure 8: Fresh weight of shoot in rice cultivar CO-51 treated with BSC and Musa spathe extracts—-pot culture experiment.

Number of tillers, length and width of flag leaf, and panicle were studied at the end of 90 DAS in which the maximum number of tillers (Figs. 10-12) was recorded in rice plants treated with MV3 and MV5 banana spathe extracts. In addition, the number of tillers correlated with the yield produced per plant (Fig. 13). A significant increase in yield was observed in Rasthali (MV5)-treated rice plants when compared to other treatments including commercially available NPK-treated rice plants (Fig. 14b). In a study conducted by Valenzuela-García et al. [34], the application of organic manure improved the yield and quality of the pepper fruits compared with the inorganic fertilizer and added to its market value. Similarly, in the present study, the maximum yield was obtained with the MV5-

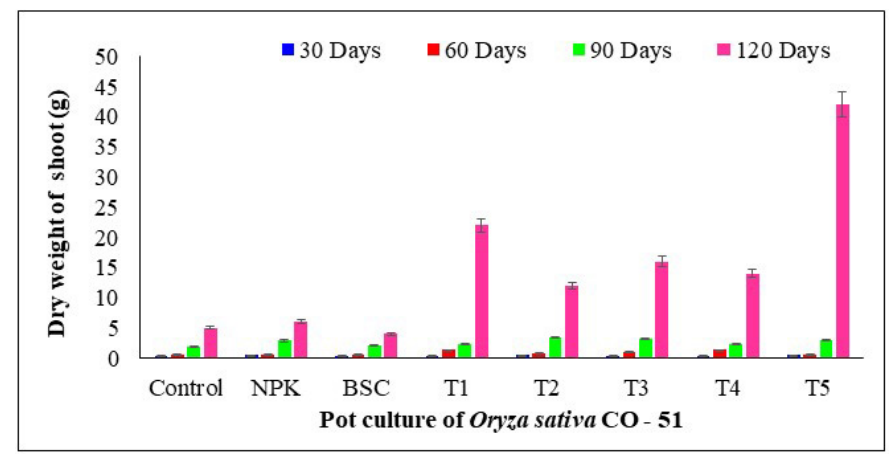

Figure 9: Dry weight of shoot in rice cultivar CO-51 treated with BSC and Musa spathe extracts_-pot culture experiment.

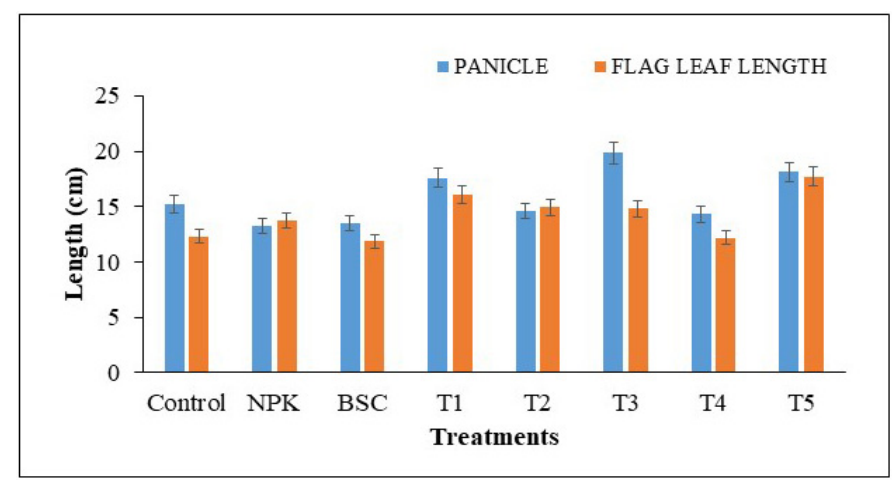

Figure 10: Length of panicle and flag leaf of treated rice plant of cultivar CO51 with BSC and Musa spathe extracts.

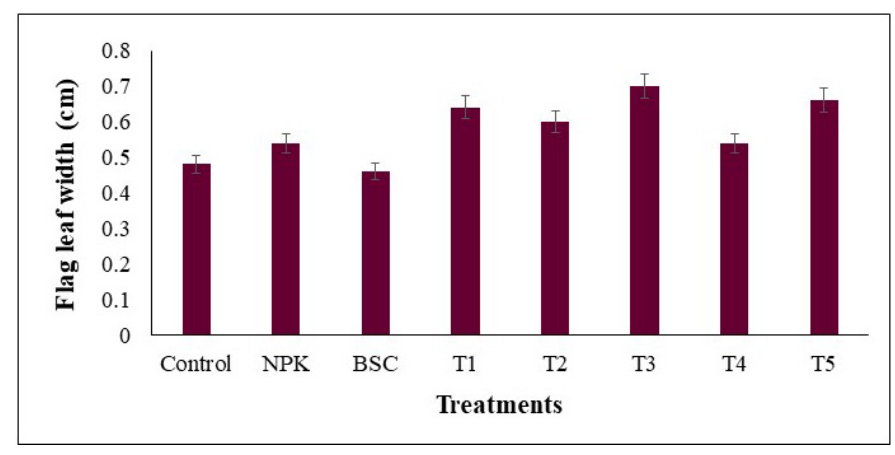

Figure 11: Width of flag leaf of treated rice plant of cultivar CO-51 with BSC and Musa spathe extracts.

treated rice plants when compared with the NPK fertilization. Different kinds of organic wastes have been used as a potential source of organic fertilizers in improving the soil fertility and crop productivity. In a study conducted by Adeoye et al. [35], different wastes like cocoa waste, plantain waste, market waste, and water hyacinth were used as a source of organic fertilizer along with NPK fertilizers that were applied to Amaranthus cruentus. The results indicated that the water hyacinth and cocoa waste promoted maximum crop growth and yield when compared with conventional NPK fertilizer similar to the present study.

Further biochemical analysis of the control and treated rice plants revealed that chlorophyll-a, chlorophyll-b and the total 


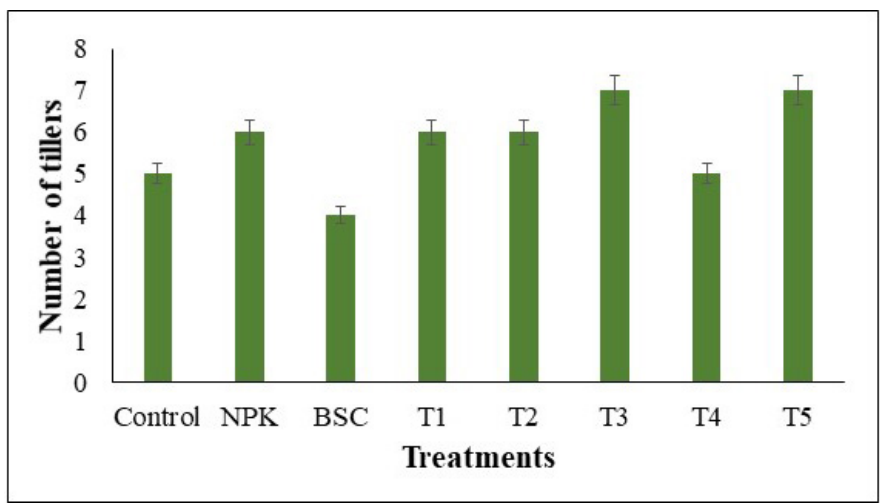

Figure 12: Number of tillers of treated rice plant of cultivar CO-51 with BSC and Musa spathe extracts.

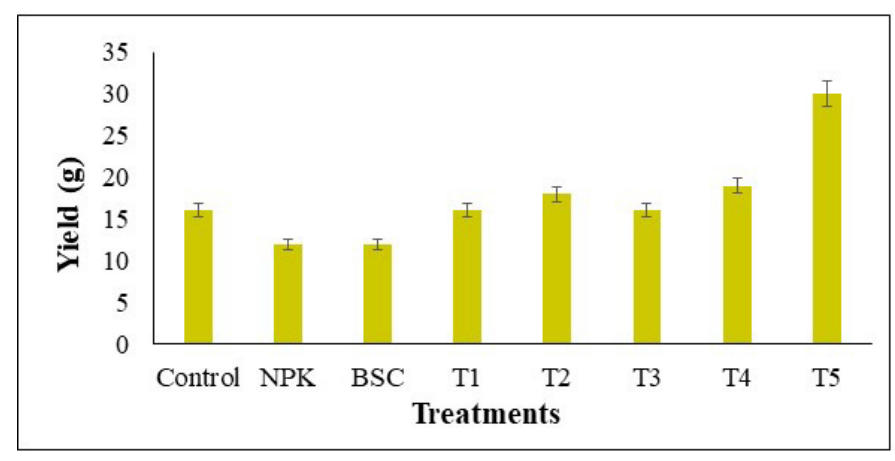

Figure 13: Yield of treated rice plant of cultivar CO-51 with BSC and Musa spathe extracts.

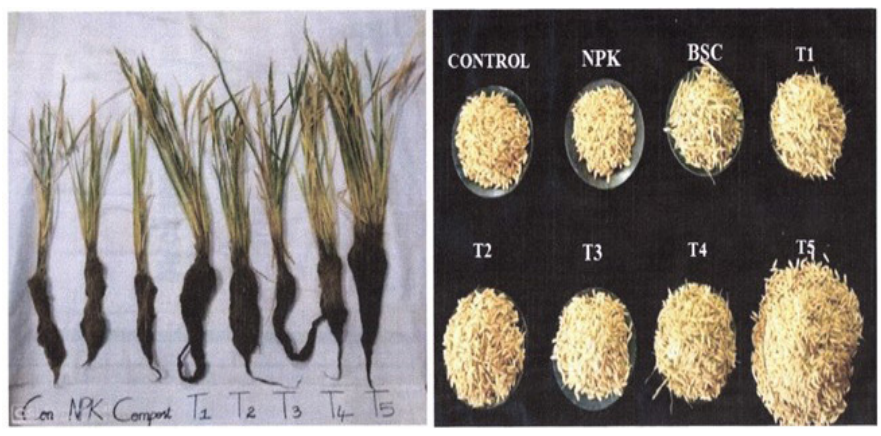

Figure 14: (a) Treated rice plants of cultivar CO-51 showing increased root and shoot lengths against control (120 DAS). (b) Treated rice plants of cultivar CO-51 showing yield variation after 120 DAS.

chlorophyll was maximum in the leaves of rice plants treated with MV4 (Elaki spathe extract; Fig. 15). An increase in the chlorophyll content is suggestive of the fact that the BSC aids in increased photosynthesis, thereby promoting the overall growth of the rice plants. Such an increase in chlorophyll content has been reported in sorghum plants treated with poultry manure [36]. However, the carotenoid content was found to be maximum in NPK-treated rice plants (Fig. 16).

There was a significant increase in the glucose, protein, and amino acid content in treated rice plants of cultivar CO-51 when compared to the control plants (Fig. 17). The concentration of glucose, protein, and amino acid content was found to be

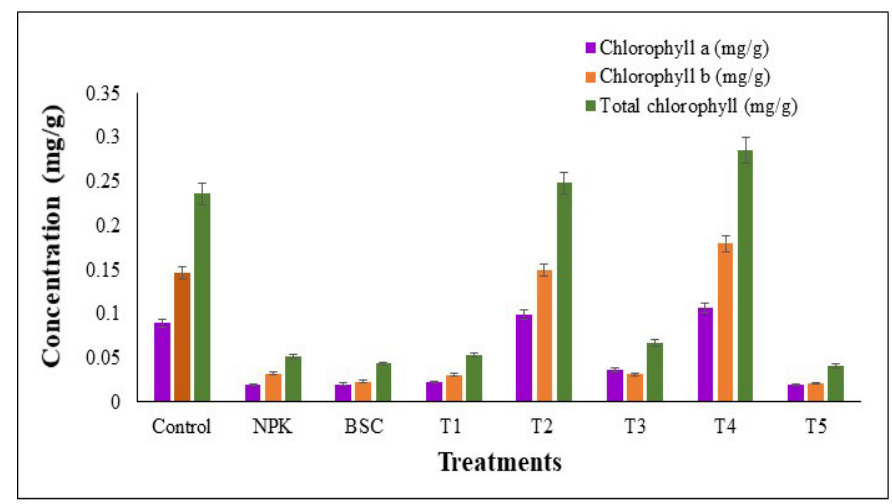

Figure 15: Estimation of chlorophyll $\mathrm{a}, \mathrm{b}$ and total chlorophyll in rice cultivar CO-51 treated with BSC and Musa spathe extracts.

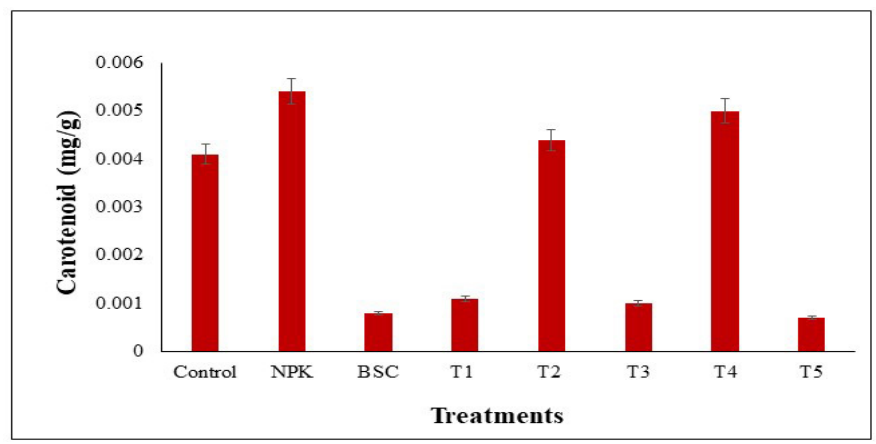

Figure 16: Estimation of carotenoid in rice cultivar CO-51 treated with BSC and Musa spathe extracts.

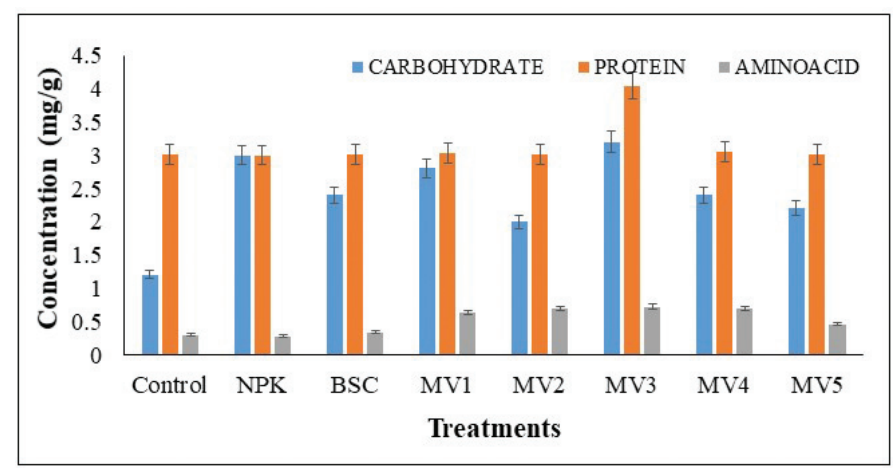

Figure 17: Estimation of carbohydrates, aminoacids and protein rice cultivar CO-51 treated with BSC and Musa spathe extracts.

maximum in MV3 (plantain spathe extract)-treated rice plants. An increase in biomolecules, such as the above, has been observed in experiments conducted in sunflower plants treated with rice husk compost. The treated plants showed an increased level of total carbohydrate and protein content when compared with the control [37]. Similar results were also observed by Deshpande and Devasenapathy [38] in rice plants treated with green manure along with FYM and poultry manure.

\section{CONCLUSION}

The current research work is focused on the utilization of banana spathe, a usually neglected agrowaste, as raw material for the 
preparation of organic compost. The efficiency of the compost was assessed with the rice cultivar CO-51, a variety grown popularly in Tamil Nadu, India. The results indicate that the utilization of banana spathe in a proper way can promote soil fertility and minimize the use of synthetic fertilizer. Pot culture experiment with rice plants showed the potential of BSC, as well as the extracts, in promoting the growth in terms of yield and biochemical parameters. It is an ecofriendly approach to provide a better solution for reducing landfills and to recycle nutrients in the soil.

\section{ACKNOWLEDGMENT}

The authors would like to thank profoundly the Head, Department of Plant Biology and Plant Biotechnology and the Principal, Ethiraj College for Women (Autonomous), Chennai for providing the instrumentation facilities through the Central Instrumentation Centre to complete this research work.

\section{AUTHOR CONTRIBUTIONS}

All authors made substantial contributions to conception and design, acquisition of data, or analysis and interpretation of data; took part in drafting the article or revising it critically for important intellectual content; agreed to submit to the current journal; gave final approval of the version to be published; and agree to be accountable for all aspects of the work. All the authors are eligible to be an author as per the international committee of medical journal editors (ICMJE) requirements/guidelines.

\section{FUNDING}

There is no funding to report.

\section{CONFLICT OF INTEREST}

The authors declare that there is no conflict of interest.

\section{ETHICAL APPROVALS}

This study does not involve experiments on animals or human subjects.

\section{REFERENCES}

1. Amanullah, Khalid S, Imran, Khan HA, Arif M, Altawaha AR, et al. Organic matter management in cereals based system: symbiosis for improving crop productivity and soil health. In: Lal R (ed.). Francaviglia $\mathrm{R}$ editors sustainable agriculture reviews, Springer, Berlin/Heidelberg, Germany, pp 67-92, 2019

2. Amanullah and Khalid, S. Agronomy- Food Security- Climate Change and the Sustainable Development Goals. In: Agronomy-Climate Change \& Food Security, Dr. Amanullah (editor) Intechopen, Pakistan pp 1-9, 2020.

3. Guimarães DV, Gonzaga MI, da Silva TO, da Silva TL, da Silva Dias N, Matias MI. Soil organic matter pools and carbon fractions in soil under different land uses. Soil Tillage Res 2013;126:177-82.

4. Demir Z, Gülser C. Effects of rice husk compost application on soil quality parameters in greenhouse conditions. Eurasian J Soil Sci 2015;4(3):185.

5. Siddiqui $\mathrm{Y}$, Meon $\mathrm{S}$, Ismail R, Rahmani M. Bio-potential of compost tea from agro-waste to suppress Choanephora cucurbitarum L. the causal pathogen of wet rot of okra. Biol Control 2009;49(1):38-44.
6. de Sotillo DR, Hadley M, Holm ET. Potato peel waste: stability and antioxidant activity of a freeze-dried extract. J Food Sci 1994;59(5):1031-3

7. Larrauri JA. New approaches in the preparation of high dietary fibre powders from fruit by-products. Trends Food Sci Technol 1999;10(1):3-8

8. Wolfe K, Wu X, Liu RH. Antioxidant activity of apple peels. J Agric Food Chem 2003;51(3):609-14.

9. Olaniyi JO. Growth, seed yield and nutrient composition of egusi melon cultivars as affected by NPK 15-15-15 fertilization. J Agric Biotechnol Environ 2000;2(1/2):11-6.

10. Mahboub Khomami A. The possibility using the composted peanut shells in the growth of marigold and Viola tricolor plants. J Ornamental Plants 2015;5(1):61-6.

11. Kaur P, Kocher GS, Taggar MS. Enhanced bio-composting of rice straw using agricultural residues: an alternate to burning. Int J Recycl Org Waste Agric 2019;8(1):479-83.

12. Carabassa V, Domene X, Alcañiz JM. Soil restoration using compostlike-outputs and digestates from non-source-separated urban waste as organic amendments: limitations and opportunities. J Environ Manag 2020;255:109909.

13. Mohapatra D, Mishra S, Sutar N. Banana and its by-product utilisation: an overview. J Sci Ind Res 2010;69(5):323-9.

14. Ruthmann AC. Methods in cell research. Cornell University Press, New York, NY, 1970.

15. Inckel $\mathrm{M}$, de Smet $\mathrm{P}$, Tersmette $\mathrm{T}$, Veldkamp $\mathrm{T}$. The preparation and use of compost. 7th edition, Agromisa Foundation: Wageningen, Netherlands, 2005.

16. Harborne JB. Phytochemical methods a guide to modern techniques of plant analysis. 3rd edition, Chapman and Hall, London, UK, 1998.

17. Gordon SA, Weber RP. Colorimetric estimation of indoleacetic acid. Plant Physiol 1951;26(1):192.

18. Khanavi M, Saghari Z, Mohammadirad A, Khademi R, Hadjiakhoondi A, Abdollahi M. Comparison of antioxidant activity and total phenols of some date varieties. DARU 2009;17(2):104-8.

19. Arnon DI. Copper enzymes in isolated chloroplasts. Polyphenoloxidase in Beta vulgaris. Plant Physiol 1949;24(1):1.

20. Marshall JD. Drought and shade interact to cause fine-root mortality in Douglas-fir seedlings. Plant Soil 1986;91(1):51-60.

21. Bradford MM. A rapid and sensitive method for the quantitation of microgram quantities of protein utilizing the principle of protein-dye binding. Anal Biochem 1976;72(1-2):248-54.

22. Yemm EW, Cocking EC, Ricketts RE. The determination of aminoacids with ninhydrin. Analyst 1955;80(948):209-14.

23. Hapsoh H, Gusmawartati G, Yusuf M. Effect various combination of organic waste on compost quality. J Trop Soils 2015;20(1):59-65.

24. Chaher NE, Chakchouk M, Nassour A, Nelles M, Hamdi M. Potential of windrow food and green waste composting in Tunisia. Environ Sci Pollut Res 2020;29:1-3.

25. Ogbonna OA, Izundu AI, Okoye NH, Ikeyi AP. Phytochemical compositions of fruits of three Musa species at three stages of development. IOSR J Pharm Biol Sci 2016;10(74):16948-52.

26. Mary CFG, Mathew SK. Efficacy of lignophenolic composts for the management of bacterial wilt of tomato. J Biol Control 2016;30(1): $55-9$.

27. Joseph J, Paul D, Kavitha MP, Dineshkumar B, Menon JS, Bhat AR, et al. Preliminary phytochemical screening and in vitro antioxidant activity of Banana flower (Musa paradisiaca AAB Nendran variety). J Pharm Res 2014;8(2):144-7.

28. Ahmad R, Khalid A, Arshad M, Zahir ZA, Mahmood T. Effect of compost enriched with $\mathrm{N}$ and L-tryptophan on soil and maize. Agron Sustain Dev 2008;28(2):299-305.

29. Badar R, Khan M, Batool B, Shabbir S. Effects of organic amendments in comparison with chemical fertilizer on cowpea growth. Int J Appl Res 2015;1(5):66-71. 
30. Thiyageshwari S, Gayathri P, Krishnamoorthy R, Anandham R, Paul D. Exploration of rice husk compost as an alternate organic manure to enhance the productivity of blackgram in typic haplustalf and typic rhodustalf. Int J Environ Res Public Health 2018;15(2):358.

31. Olaniyi JO, Ojetayo AE. Effect of fertilizer types on the growth and yield of two cabbage varieties. J Anim Plant Sci 2011;12(2):1573-82.

32. Ipinmoroti RR, Akanbi OSO. Comparison of organic nutrient sources with NPK for cashew seedlings growth towards organic cashew farming in Nigeria. Int J Plant Soil Sci 2015;4(2):185-91.

33. Lee JJ, Park RD, Kim YW, Shim JH, Chae DH, Rim YS, et al. Effect of food waste compost on microbial population, soil enzyme activity and lettuce growth. Bioresour Technol 2004;93(1):21-8.

34. Valenzuela-García AA, Figueroa-Viramontes U, Salazar-Sosa E, Orona-Castillo I, Gallegos-Robles MÁ, García-Hernández JL, et al. Effect of organic and inorganic fertilizers on the yield and quality of jalapeño pepper fruit (Capsicum annuum L.). Agriculture 2019;9(10):208.

35. Adeoye GO, Sridhar MKC, Ipinmoroti RR. Potassium recovery from farm wastes for crop growth. Commun Soil Sci Plant Anal 2001;32(15-16):2347-58.

36. Amujoyegbe BJ, Opabode JT, Olayinka A. Effect of organic and inorganic fertilizer on yield and chlorophyll content of maize (Zea mays L.) and sorghum Sorghum bicolour (L.) Moench. Afr J Biotechnol 2007;6(16):1869-73.
37. Badar R, Qureshi SA. Composted rice husk improves the growth and biochemical parameters of sunflower plants. J Bot 2014;2014:1-6.

38. Deshpande HH, Devasenapathy P. Effect of green manuring and organic manures on yield, quality and economics of rice (Oryza sativa L.) under lowland condition. Karnataka J Agric Sci 2010;23(2):235-8.

\section{How to cite this article:}

Suganthi S, Kavitha SK. Application of banana spathe extracts and compost for improving growth in rice plants. J Appl Biol Biotech 2022; 10(01):112-119. 